\title{
INVESTIGATION OF THE EFFECTS OF THE COVID-19 PANDEMIC ON THE OPERATION DECISION OF THE PATIENTS
}

\author{
Cem Ece ${ }^{1}$, Seyda Canli ${ }^{2}$, Ece Basak Unal ${ }^{3}$, Orhan Cakir ${ }^{4}$
}

\footnotetext{
${ }^{1}$ Izmir Tinaztepe University, Galen Hospital Anesthesiology and Reanimation Clinic, Izmir, Turkey

${ }^{2}$ Izmir Tinaztepe University, Galen Hospital Anesthesiology and Reanimation Clinic, Izmir, Turkey

${ }^{3}$ Izmir Tinaztepe University, Galen Hospital Department of Clinical Psychology, Izmir, Turkey

${ }^{4}$ Izmir Tinaztepe University, Vocational School of Health Services, Izmir, Turkey
}

Corresponding Author: Cem Ece, E-mail: cemece.dr@gmail.com

Received: 30.07.2021; Accepted: 18.08.2021; Available Online Date: 27.01 .2022

CCopyright 2021 by Dokuz Eylül University, Institute of Health Sciences - Available online at https://dergipark.org.tr/en/pub/jbachs

Cite this article as: Ece C, Canli S, Basak-Unal E, Cakir O. Investigation of the Effects of the COVID-19 Pandemic on the Operation Decision of the Patients. J Basic Clin Health Sci 2022; 6: 1-8.

\begin{abstract}
Purpose: The COVID-19 pandemic has had significant impacts on healthcare organizations and patients. In our study, the effect of the pandemic period and the application of PCR test results on the decision to perform the operation were investigated.

Material and Method: 300 patients who applied to the Anesthesia outpatient clinic of Private Tınaztepe Galen Hospital Anesthesia Outpatient Hospital were included in our study. In the collection of data, the Individual Introduction Form with 17 questions prepared by the research team in line with the literature was used. Statistical analyzes were performed using IBM ${ }^{\circledR}$ SPSS $® 22$ (SPSS Inc., Chicago, IL, USA) software. The conformity of the variables to the normal distribution was examined using analytical methods (Kolmogorov-Smirnov/Shapiro-Wilk tests).

Results: In our study, 50 patients (16.7\%) reported that the pandemic caused a change in the decision to undergo surgery. This rate was found to be $12.1 \%(n=20)$ in patients who will undergo elective surgery and $22.2 \%(n=30)$ in patients who will undergo emergency or oncological surgery. In our study, it was determined that the effect of the pandemic on the operation decision was not affected by gender, age and educational status. The effect of the pandemic on the operation decision was found to be statistically significantly higher in patient groups who had Covid19 infection in themselves or in their immediate surroundings during the pandemic period. Likewise, all of the people who lost their lives due to Covid-19 in their immediate vicinity stated that there was a change in the operation decision. It was observed that the pandemic had no effect in the process of giving a new operation in patients who had been operated during the pandemic period. $90.4 \%(n=122)$ of those who will undergo emergency or oncological surgery answered "I would not have been operated on if there was an elective operation". It was observed that PCR had an effect on the decision-making process in all patient groups.

Conclusion: The results of our study showed that the pandemic was closely followed by all patient groups and that demographic data did not affect the operation decision of the patient groups; It has been shown that he or his close friends have been affected by the Covid 19 infection and the losses are effective in the decision-making process. The reliability of health institutions during the pandemic process is also effective in the decision-making process. According to the PCR test results, admission to the operating room was effective in the decision-making process for all patient groups.
\end{abstract}

Keywords: Covid-19 pandemic, PCR, operation decision

\section{INTRODUCTION}

The coronavirus (COVID-19) that has emerged in

Province. The high level of contagiousness and the December 2019 in the city of Wuhan, China's Hubei pandemic it created have made this virus an 
important public health problem $(1,2)$. The physical environment of operating rooms, the number of employees, intubation and invasive procedures make these areas particularly high risk.

Although the number of Covid-19 infected individuals is recorded all over the world with the developments in diagnostic methods and screening programs, the progress of the epidemic has caused the hospital work load to increase significantly. In this process, emergency room workers, outpatients, intensive care units and operating room workers are at high risk for exposure to the disease (3). The physical environments of operating rooms, the number of employees, intubation and invasive procedures make these areas particularly high-risk.

Elective surgery cases have been postponed in the early stages of the Covid-19 pandemic. All surgical services are structured to accept Covid-19 patients. The operating room systems of hospitals in our country are generally well-designed to deal with such high-risk situations. However, the high risk of contamination and limited resources greatly increase the risk and burden on team members performing surgical procedures. With the progress of the process, a road map has begun to be created in line with new information for surgical applications (4-8). In the later stages of the pandemic, studies on safe surgical application algorithms related to possible or definite Covid-19 diseased cases have begun to be published (8).

In our study, it was aimed to investigate the effect of the pandemic period, demographic variables of the patients, and admission to the operating room by taking PCR test on the decision of the patients to undergo surgery.

\section{METHOD}

\section{Type of Research}

This study is a descriptive study.

\section{Population and Sample of the Research}

The population of the study consisted of 300 patients who applied to the Private Tinaztepe Galen Hospital Anesthesia outpatient clinic between 01.01.2021 and 30.04.2021. Patients under the age of 18 and patients with dementia or Alzheimer's diagnosis were not included in the study.

\section{Data Collection}

In the collection of data, the Individual Introduction Form with 17 questions prepared by the research team in line with the literature was used. It took approximately 5 minutes for a patient to fill out the relevant form.

Individual Introduction Form: This form consists of questions that include information on age, gender, educational status and marital status, as well as introductory features about COVID-19.

\section{Evaluation of Data}

Statistical analyzes were performed using IBM ${ }^{\circledR}$ SPSS ${ }^{\circ} 22$ (SPSS Inc., Chicago, IL, USA) software. The conformity of the variables to the normal distribution was examined using analytical methods (Kolmogorov-Smirnov/Shapiro-Wilktests).

Descriptive statistics; The mean \pm standard deviation values were given. Frequency and percentage values were given for discrete (categorical) variables. The ttest was used to analyze continuous data between independent groups. Pearson's Chi-square or Fisher's Exact Chi-square analyzes were used to compare discrete data. Cases with a p-value below 0.05 were considered statistically significant.

\section{Ethical Approval}

In order to carry out the study, ethical approval was obtained from the Non-Interventional Clinical Research Ethics Committee of Tinaztepe University School of Medicine. Participants were informed about the research before the application and their verbal consent was obtained.

\section{RESULTS}

A total of 300 patients, 151 women $(50.3 \%)$ and 149 men (49.7\%), who applied to the Private Tinaztepe Galen Hospital Anesthesiology and Reanimation outpatient clinic between 01.01.2021 and 30.04.2021 were included in our study. The mean age of the patients was $47.7 \pm 17.5$. Demographic data of the patients are shown in Table 1.

In our study, 30 (10\%) patients diagnosed with Covid19 infection during the pandemic process, 154 (51.3\%) patients diagnosed with Covid-19 infection in their relatives, and $44(16.5 \%)$ patients who lost their lives due to Covid-19 infection in their relatives were detected.

Among the patients included in the study, 176 $(58.7 \%)$ patients were informed about the developments regarding the pandemic from social media; It was observed that 225 patients $(75.0 \%)$ were followed by television, $43(14.3 \%)$ from the written media, and $75(25.0 \%)$ from their social 
Table 1. Demographic Information of Participants

\begin{tabular}{llcc}
\hline \multicolumn{1}{c}{ Variables } & Subgroups & Mean & Min-Maks \\
\hline Age & & $47,7 \pm 17,5$ & $18-83$ \\
\hline Gender & & $\mathbf{n}$ & $\%$ \\
& Male & & \\
& Female & 149 & 49,7 \\
Marital status & & 151 & 50,3 \\
& Single & & \\
& Married & 68 & 22,7 \\
Educational Status & & 232 & 77,3 \\
& Primary school & & \\
& Secondary School & 70 & 23,3 \\
& High School & 28 & 9,3 \\
& University & 88 & 29,3 \\
& Master & 101 & 33,7 \\
& PhD & 7 & 2,3 \\
& & 6 & 2,0 \\
\hline
\end{tabular}

environment. Six patients $(2 \%)$ who participated in the study reported that they did not follow the up to date data related to Covid-19. It was determined that 225 patients who participated in our study had previously undergone one or more surgical procedures under anesthesia. Procedures requiring anesthesia general surgery in 69 patients $(30.6 \%)$, gynecology and obstetrics in 46 patients (20.4\%), urology in 37 patients $(1.4 \%)$, gynecology and obstetrics in 32 patients (14.3\%), Orthopedics in 22 patients $(9.7 \%)$, gastroenterological procedure in 22 patients $(9.7 \%)$, Otorhinolaryngology in 21 patients $(9.3 \%)$, Aesthetic and plastic surgery in 15 patients $(6.6 \%), 5$ patients $(2 \%, 2)$ cardiovascular surgery, neurosurgery in $4(1.8 \%)$ patients, interventional radiology in 4 patients $(1.8 \%)$, and eye procedures in 2 patients $(0.9 \%)$. It was determined that $50(16.7 \%)$ patients had undergone one or more surgical procedures during the pandemic period. Procedures requiring anesthesia were urology in 15 patients $(30 \%)$, general surgery in 13 patients $(26 \%)$, and gastroenterological procedures in 8 patients (16\%). neurosurgery in 5 patients $(10 \%)$, aesthetic and plastic surgery in 3 patients $(6 \%)$, orthopedics in 3 patients $(6 \%)$, interventional radiology in 2 patients $(4 \%)$, obstetrics in 1 patient $(2 \%), 2)$ It was ENT procedures. 51 patients reported that their close relatives had undergone an operation during the pandemic period. Among the patients included in the study, it was observed that 135 patients $(44.7 \%)$ applied to the outpatient clinic due to emergency or oncological operation, and 165 patients (55.0\%) due to elective operation. When the effect of the Covid-19 pandemic on the operation decision of the patients was examined, 50 patients $(16.7 \%)$ reported that the pandemic caused a change in the decision to undergo surgery. This rate was found to be $12.1 \%$ $(n=20)$ in patients who will undergo elective surgery and $22.2 \% \quad(n=30)$ in patients who will undergo emergency or oncological surgery. This rate was found to be statistically significant $(p=0.020) .250$ patients stated that the pandemic had no effect on the operation decision. $122(97.6 \%)$ of the patients $(n=135)$ who will have an emergency or oncological operation gave the answer "I would not have thought of being operated if there was an elective operation". When the patients were asked about the effect of admitting to the operating room on the decision of the operation according to the results of the PCR test, 270 patients $(90.0 \%)$ answered that there was an effect, 30 patients $(10.0 \%)$ said that there was no effect. This rate was found to be $142(86.1 \%)$ for 165 patients who will undergo elective surgery, and 128 (94.8\%) for patients who will undergo emergency or oncologic surgery. This rate is statistically significant $(p=0.012)$. When the effects of demographic data were examined, the effect of the pandemic period on 
1 Table 2. Distribution of Participants' Responses to the Survey Questions

\begin{tabular}{llll}
\hline Variables & Subgroups & $\mathbf{n}$ & $\%$
\end{tabular}

Have you been COVID during the Pandemic Process?

No

270

30

90

Yes

Did one or more people you know have COVID during the pandemic process?

No

Yes

Getting Information on the Pandemic*

\section{Social media}

176

TV

225

Printed Press

14,3

Social Environment

Have you had any previous surgery?

$$
\text { No }
$$

Yes

Have you had any previous surgery?

No

Have your relative/s had any operation during the COVID pandemic?

Status of Change in the Decision to Operate in the Pandemic

No, I will be operating.

Yes, I gave up/postponed.

Which Type of Operation Will Be Performed

Emergency or Oncological Surgery

If there is an elective operation

PCR Test Effect

\footnotetext{
* More than one selection has been made.
} 
in the female patient group and $18.8 \% \quad(n=28$ patients) in the male patient group. This rate was not statistically significant $(p=0.327)$.

The effect of PCR on the decision of operation was found $88.1 \%(n=133)$ in women and $91.9 \%(n=137)$ in men. This rate was not statistically significant $(p=0.264)$.

When the effect of the pandemic on the decision of operation was analyzed according to education level, it was found that $18.6 \%(n=13)$ of primary school graduates, $28.6 \% \quad(n=8)$ of secondary school graduates, and $14.8 \% \quad(n=13)$ of high school graduates. These rates were $13.9 \% \quad(n=14)$ in university graduates, $14.3 \% \quad(n=1)$ in graduate students, and $16.7 \% \quad(n=1)$ in doctoral students. These rates were not statistically significant $(p=0.569)$.

When the effect of PCR on the operation decision was analyzed according to education level, it was found that $88.6 \%(n=62)$ of primary school graduates, $96.4 \%(n=27)$ of secondary school graduates, and $93.2 \%(n=82)$ of high school graduates. These rates were found to be $85.1 \% \quad(n=86)$ for university graduates, $100 \%(n=7)$ for graduate students, and $100 \%(n=6)$ for doctoral students. The effect of these ratios was not statistically significant. $(p=0.259)$.

$26.7 \%(n=8)$ of the patients $(n=30)$ who had Covid-19 infection during the pandemic period indicated that there was a change in the operation decision $(p=0.121)$

$12.3 \%(n=19)$ of those $(n=154)$ who had Covid-19 infection in their immediate surroundings during the pandemic period stated that there was a change in the operation profit. $(p=0.039)$. In these patients, the effect of PCR on the operation profit was found to be $94.2 \%(n=145) .(p=0.014)$ Both rates were found to be statistically significant. All of the people who lost their lives due to Covid-19 in their immediate vicinity stated that there was a change in the operation decision. This rate was $40 \%$ in those who did not experience loss.

$14.6 \%(n=33)$ of the patients who had a previous operation $(n=226)$ stated that the pandemic caused a change in the operation decision. $(p=0.094)$ This rate was found to be statistically significant. $12 \%(n=6)$ of the patients $(n=50)$ who were operated during the pandemic period stated that there was a change in their decisions and no statistically significant difference was found $(p=0.332)$.

$90.4 \% \quad(n=122)$ of those who would have an emergency or oncological operation $(n=135)$ answered "I would not have been operated on if there was an elective operation." This rate was found to be statistically significant $(p=0.0001)$.

The Distribution of Responses to the Questionnaires of the Participants is shown in Table 2.

\section{DISCUSSION}

As in many pandemics that have caused great losses in the historical process, the Covid 19 pandemic has severely damaged the health systems of countries all over the world. In addition to the heavy losses in the countries where the measures are inadequate, the number of severe patients above the intensive care capacities in many countries has led to the necessity of making changes in the diagnosis and treatment of other diseases.

In most countries, speciality associations have prepared guidelines for the pandemic period and changed their approach to diseases (2). Two headings stood out especially for the surgical process. The first is clinical and polyclinic surgical services within the framework of social isolation rules, and the second is the principles of approach to risk groups that have to continue surgical intervention and surgical clinical processes. (9).

With the planning of mass hospitalization of Covid-19 patients, elective surgeries were postponed after the World Health Organization declared a pandemic in February 2020 and after 20 March 2020 in our country, only emergency and oncological interventions could be performed (9). A road map has begun to be created in the light of new information for surgical approaches (3-6). In addition to applications in wide areas ranging from hospital admissions to isolation measures and capacity reductions in health institutions, the most common practice for this purpose is to give approval according to the results of the PCR test during admission to the operating rooms.

In a study using data from 190 countries, over 28 million delayed cases were reported in 12 weeks. According to this study, where the rate of postponed cases was $72.3 \%, 81.7 \%$ of the postponed cases were benign surgical interventions (10).

A study conducted in our country compared the number of surgeries and the rates of malignant and elective surgery in 2020 and 2019. The study stated that the rate of elective surgery, which was $80 \%$ in 2019 , decreased to $34.5 \%$ in 2020 ; showed that the malignant/benign ratio increased from $1 / 10.9$ to $1 / 3.1$. In the study, it was also seen that while elective 
surgeries were 4 times more than emergency cases in 2019, emergency surgeries were 2 times more than elective cases in 2020 (11).

In a study conducted in the United States (USA), the effect of the Covid -19 pandemic on patients with elective planned hip and knee arthroplasty was investigated and it was determined that the biggest concern of the patients was the uncertainty of the time of surgery (12). The study also showed that while patients are concerned about contracting Covid-19, almost $90 \%$ are considering rescheduling surgery as soon as possible.

In our study, the rate of patients who admitted to the anesthesia outpatient clinic was found to be $16.7 \%$, saying that the decision of surgery was affected. While this rate was $12.1 \%$ in patients who would undergo elective surgery, it was $22 \%$ in patients who would undergo emergency or oncological surgery. Our study was conducted in patients who applied to the anesthesia outpatient clinic. We think that these rates may be higher in all patient groups.

Surgical interventions have physiological and psychological effects on patients with many variables such as the size of the operation, experiences, timing and whether it is urgent or planned. Studies show that the anxiety levels of patients hospitalized for surgery are higher than other patients, and besides many socio-demographic characteristics such as gender, occupation, knowledge of the procedures to be performed, previous anesthesia and surgical intervention experience, type, size, difficulty of the surgical intervention to be performed. and the degree of risk (13-18).

In a study investigating the effects of gender, occupation, and socioeconomic parameters on the occurrence of anxiety, it was reported that women's anxiety levels were higher than men (19).

In a study conducted in our country, anxiety levels were found to be higher in women than in men. The study also showed that anxiety levels were higher in those who came with companions than those who came alone, in young people than in the elderly, and in those who had had a negative operation or anesthesia experience compared to those who did not. In addition, the anxiety level of patients who were hospitalized for an operation was reported to be higher in the first two days following the operation from hospitalization to the operation compared to the other days (20).

In a study on pre- and postoperative anxiety in patients who underwent elective surgery, the relationship between demographic variables and preoperative and postoperative anxiety and preoperative trait anxiety score averages was examined. In the study, they found a statistically significant difference between age and postoperative anxiety. Accordingly, patients aged 43 years and younger have higher anxiety. Again, in the same study, a statistically significant difference was found between preoperative anxiety and gender, and anxiety scores were higher in women. At the same time, there was a significant difference between the education level of the patients who will undergo the operation and the anxiety level before the operation. According to this result, the post-operative anxiety score averages of the patients who graduated from secondary school were found to be higher (21).

In another study, based on the hypothesis that surgery is an important factor that may cause anxiety in patients, the relationship between the severity of anxiety and anxiety level in the preoperative period and sociodemographic characteristics was investigated. It was noted that the data did not cause a difference in the anxiety level of the patients. In the study, it was also observed that the education level of the patients and the detailed preoperative information provided a significant decrease in the anxiety level (22).

In a study in which anxiety was investigated in neurosurgery patients who underwent nonemergency surgery during the Covid-19 epidemic and 133 patients were recruited from 10 different hospitals, none of the patients developed Covid-19 after surgery.

The anxiety rates of patients with stateful and trait anxiety were reported as $30.3 \%$ and $18.9 \%$, respectively. Another finding was higher state anxiety values compared to non-oncological patients $(46.7 \%$ vs. $25 \%$ ). Anxiety, as expected, was strongly associated with anxiety about primary pathology, surgery, worsening of illness, and stress during waiting period. However, worrying about Covid-19 positivity was the strongest factor associated with anxiety, even though none of the patients were infected. Neuro-oncological disease has been associated with state anxiety and worry about surgery and Covid-19. In addition, it was noted in the study that increased bed distance and hand sanitizer availability create a sense of security for patients undergoing surgery (23).

The results of our study were not different in the male and female patient groups, unlike other studies on the 
decision of surgery and anxiety. Our study also showed that age and education had no effect on the decision-making process. We think that these results may be related to the fact that the pandemic affects all groups of the society, independent of demographic changes. As a matter of fact, according to the results of our study, the rate of patients who stated that they did not follow the developments related to the pandemic was only $2 \%$. It was determined that the patients participating in the study mostly followed the developments related to the pandemic on television and social media. The effect of the pandemic on the operation decision was found to be statistically significantly higher in the patient groups who had Covid-19 infection in themselves or in their immediate surroundings. Likewise, all of the people who lost their lives due to Covid-19 in their immediate surroundings stated that there was a change in the operation decision.

In our study, the effects of the pandemic on the decision of a new operation of the patients who had an operation in the previous periods and during the pandemic period were also evaluated. Our study showed that while the pandemic process had an effect on the decision-making process, it had no effect in the process of giving a new operation in patients who had been operated during the pandemic period. $90.4 \% \quad(n=122)$ of those who would have an emergency or oncological operation answered "I would not have been operated on if there was an elective operation". This rate was found to be statistically quite significant.

During the pandemic process, the functioning and reliability of health institutions have also been effective in patients' hospital admission and operation decisions. General conditions such as the speed of the pandemic, the number of patients and deaths, the speed of the pandemic in the center, the number of deaths, and the reliability of the center where the operation will be performed can be shown among the effective factors. In addition to other applications that will reduce the risk of transmission, the PCR test requirement, which is accepted as the most sensitive diagnostic method of Covid-19 infection, is considered among the most effective measures in the world when patients are admitted to the operating room. In our study, the effect of admission to the operating room according to the results of the PCR test was also investigated. The effect of PCR on the operation decision was high in all groups independent of demographic data.
The results of our study showed that the pandemic was closely followed by all patient groups and that demographic data did not affect the operation decision of the patient groups; It has been shown that he or his immediate surroundings have been affected by the Covid 19 infection and the loss of life is effective in the decision-making process. The reliability of health institutions during the pandemic process is also effective in the decision-making process. According to the PCR test results, admission to the operating room was found to be effective in the decision-making process for all patient groups. In the continuation of the pandemic process, different applications may gain importance in ensuring the reliability of the institution in the operation decision of the patients.

Author contributions: CE: Writing the manuscript, editing the manuscript and collection of data. SC: Review of the literature and collection of data. EBU: Review of the literature. OC: Collection of data.

Conflict of Interest: No conflict of interest was declared by the authors.

Ethical approval: Ethical approval was obtained from the Non-Interventional Clinical Research Ethics Committee of Tinaztepe University School of Medicine.

Peer-review: Externally peer-reviewed.

\section{REFERENCES}

1. Yürük $E B$, Çelik $H$. COVID-19 salgını ile mücadelede hemşirenin rolü. Türkiye Klinikleri J Nurs Sci. 2020;12(2):300-4.

2. Alimoğlu $\mathrm{O}$, Erol Cl. Covid-19 Pandemisi Sırasında Genel Cerrahi Uygulamalarına Yaklaşım . Anatolian Clinic the Journal of Medical Sciences. 25(Special Issue on COVID 19), 102110.

3. World Health Organization. [WHO] (2020b). Coronavirus disease (COVID-19) outbreak: rights, roles and responsibilities of health workers, including key considerations for occupational safety and health. World Health Organization, Interim guidance, 19. Retrieved June, 8, 2020.

4. Kaptan H, Kasımcan MÖ, Yılmaz M. COVID-19 VE CERRAHI YAKLAŞıM. Gazi Sağlık Bilimleri Dergisi 2020: Özel Sayı: 97-102

5. He F, Deng Y, Li W. Coronavirus disease 2019: What we know? J Med Virol. 2020;92(7):719-725.

6. Lu R, Zhao $X, \mathrm{Li} J$, et al. Genomic characterisation and epidemiology of 2019 novel coronavirus: implications for virus origins and 
receptor binding. Lancet. 2020 Feb 22;395(10224):565-574.

7. Wu Z, McGoogan JM. Characteristics of and Important Lessons From the Coronavirus Disease 2019 (COVID-19) Outbreak in China: Summary of a Report of 72314 Cases From the Chinese Center for Disease Control and Prevention. JAMA. 2020;323(13):1239-1242.

8. Karaca AS, Özmen MM, Uçar AD, Yastı AÇ, Demirer S. COVID-19'lu hastalarda genel cerrahi ameliyathane uygulamaları. Turk J Surg 2020; 36 (1): VI-X.

9. Albuz Ö, Uludağ M. Covid-19 Pandemisi ve Cerrahi Perspektivite Üzerine Etkileri. Avrasya Sağlık Bilimleri Dergisi (2020): 3(COVID-19), 116-119.

10. COVIDSurg Collaborative, Elective surgery cancellations due to the COVID-19 pandemic: global predictive modelling to inform surgical recovery plans, British Journal of Surgery, Volume 107, Issue 11, October 2020, Pages 1440-1449,

11. İlhan E, Öztop M, Üreyen O, Yıldırım M. COVID19 Pandemisinin Genel Cerrahi Kliniğinde Acil Ve Elektif Cerrahi Girişimlere Olan Etkisinin Değerlendirilmesi: Kesitsel Çalışma. Ankara Eğitim ve Araştırma Hastanesi Tıp Dergisi. 2020; 53(3): 202-205.

12. Brown $\mathrm{E}$ at al. The potential impact of COVID-19 on psychosis: A rapid review of contemporary epidemic and pandemic research. Schizophr Res. 2020 Aug;222:79-87.

13. Karayağız F, Altuntaş $M$, Güçlü $A Y$, Yılmazer YT, Öngel K. Cerrahi servisinde yatan hastalarda görülen anksiyete dağılımı Anxiety distrubution observed at surgery patients. Smyrna Tıp Dergisi 2011; 22-25.

14. Cimilli C. Cerrahide Anksiyete. Klinik Psikiyatri. 2001; 4: $182-86$.

15. Kırlı S. Anksiyete Bozukluklarının Oluşumu ve Farmakolojik Tedavisi - Anksiyetenin Oluşumu ve Anksiyete ile İlişkili Psikolojik ve Fizyolojik Süreçler. 2000 Bursa: Psikiyatri ve Sanat Yayınevi.

16. Weanar C. Kaygı Bozuklukları ve Aşırı Kontrol: Stres ve Stresle Başa Çıkma Yolları. Çeviren: Türköz, Y., Türk Psikoloji Bülteni. 2003; 9(30 31): 97 - 106.

17. Gürsoy A. Ameliyat Öncesi Hastaların Kaygı Düzeyleri ve Kaygıya Neden Olabilecek Etmenlerin Belirlenmesi. Hemşirelikte Araştırma
- Geliştirme Dergisi, 2001;1:23 - 30

18. Yardakçı R, Akyolcu N. Ameliyat Öncesi Dönemde Yapılan Hasta Ziyaretlerinin Hastanın Anksiyete Düzeyine Etkisi. Hemşirelikte Araştırma Geliştirme Dergisi, 2004;1:7 - 14.

19. Karancı N, Dirik G. Predictors of Pre - and Postoperative Anxiety in Emergency Surgery Patient Journal Psychosom Research, 2003; 55(4): $363-69$.

20. Turhan Y, Avcı R, Özcengiz D. Elektif Cerrahi Hazırlığında Preoperatif ve Postoperatif Anksiyetenin Hasta Memnuniyeti ile İlişkisi Journal of Anesthesia 2012; 20(1): 27 - 33

21. Yılmaz E, Aydın E. Cerrahi Girişim Yapılan Hastalarda Ameliyat Öncesi-Sonrası Anksiyetenin Derlenme Kalitesine Etkisi Fırat Sağlık Hizmetleri Dergisi, 2013;8(23), 80-95.

22. Demir A, at al. Kalp cerrahisi geçirecek olgularda anksiyete sağaltımı. Türk Göğüs Kalp Damar Cerrahisi Dergisi 2010;18(3):177-82

23. Doglietto $F$. at al Anxiety in neurosurgical patients undergoing nonurgent surgery during the COVID-19 pandemic Neurosurg Focus. 2020;49(6):E19. 